\title{
MUATAN NILAI DAN PRINSIP PIAGAM MADINAH DAN PANCASILA: Analisa Perbandingan
}

\section{Mukhlis Fahruddin}

Fakultas Tarbiyah, UIN Maulana Malik Ibrahim Malang

Jl. Gajayana No. 50 Malang, email: Mukhlis_fahruddin@yahoo.com Telp.

\begin{abstract}
Madinah charter consist of humane ideas of civil society which are relevant to development and needs of world society and has become a modern way of life. Agreeing with Madinah charter Ideas, the founding fathers of Indonesia adopt it into Jakarta charter which is later called as Pancasila. The content of Madinah charter and Pancasila have smililarities as a SAWa' or a exalted agreement of humane society. Pancasila is a dignifiying submission of all the national element to establish, love and maintain Indonesia. Similarly, Madinah Charter is noble agreement to defend Madinah as a nation. Both of these charters include basic principles such as: wisdom, brotherhood, equality, tolerance, democracy, cooperation, and justice.
\end{abstract}

Piagam Madinah memuat ide-ide humanis dalam berbangsa dan bernegara yang mempunyai relevansi dengan perkembangan dan keinginan masyarakat dunia, bahkan kini telah menjadi pandangan hidup modern. Kesamaan Ide dalam Konstitusi Piagam Madinah juga ada dalam pikiran para tokoh pendiri bangsa Indonesia, yang terlihat dalam Piagam Jakarta yang kemudian muncullah Pancasila. Muatan Piagam Madinah dan Pancasila memiliki kesamaan sebagai kalimah SAW atau Perjanjian Luhur bagi masyarakat yang berperikemanusiaan (Humanis). Pancasila merupakan perjanjian luhur seluruh elemen bangsa untuk membangun, mencintai dan mempertahankan Indonesia. Sedangkan Piagam Madinah merupakan perjanjian luhur untuk mempertahankan negara Madinah. Keduanya sama-sama memuat asas dan prinsip antara lain: kearifan, persaudaraan, persamaaan, toleransi, musyawarah, tolong menolong, dan keadilan.

Key words: Madinah charter, Pancasila, Indonesia 


\section{Pendahuluan}

Setelah Nabi Muhammad SAW tiba di Madinah dan diterima penduduk Madinah, dan menjadi pemimpin penduduk kota itu. Rasulullah SAW segera meletakkan dasar-dasar kehidupan yang kokoh bagi pembentukan suatu masyarakat baru. Inilah awal berdirinya pranata sosial politik dalam sejarah perkembangan Islam. Sebagai produk yang lahir dari rahim peradaban Islam, Piagam Madinah diakui sebagai bentuk perjanjian dan kesepakatan bersama bagi kepentingan membangun masyarakat Madinah yang plural, adil, dan berkeadaban.

Piagam Madinah merupakan surat perjanjian yang dibuat pada masa Rasulullah SAW bersama dengan orang-orang Islam dan pihak lain (Yahudi) yang tinggal di Yasrib (Madinah). Piagam tersebut memuat pokok-pokok pikiran yang dari sudut tinjauan modern dinilai mengagumkan. Dalam konstitusi itulah untuk pertama kalinya dirumuskan ide-ide yang kini menjadi pandangan hidup modern, seperti kebebasan beragama, keberagaman, multikulturalism, humanism dan hak setiap kelompok untuk mengatur hidup sesuai dengan keyakinannya, kemerdekaan hubungan ekonomi, dan lain-lain. Selain itu juga ditegaskan adanya suatu kewajiban umum, yaitu partisipasi dalam usaha pertahanan bersama menghadapi musuh dari luar, dan menjunjung tinggi nilai-nilai humanis (Karvallo,dkk., 1983: 11).

Melihat prinsip-prinsip pokok yang terdapat dalam Piagam Madinah, agaknya tidak berlebihan kalau Pancasila, dasar Negara Indonesia, dapat dibandingkan sekalipun tidak dapat disamakan dengan prinsip-prinsip yang dikandung Piagam Madinah. Kedudukan dan fungsi Pancasila pun bagi Umat Islam Indonesia kiranya ada persamaan. Hal ini dapat dimaklumi bahwa lahirnya Pancasila merupakan obyektifikasi Islam, yaitu penerjemahan nilainilai internal ke dalam kategori-kategori objektif. Obyektifitas inilah yang akan menghindarkan masyarakat dari dominasi (Karim, 2004: 46).

Para bapak bangsa pencetus Pancasila, yang mayoritas muslim, mereka tidak menjadikan Negara Indonesia sebagai Negara Islam. Mereka juga tidak menggunakan bahasa maupun simbol-simbol Islam dalam membentuk pemerintahan. Mereka tidak memilih negara Islam, karena mereka menyadari, kalau bahasa-bahasa simbol itu dapat menimbulkan resistensi dari kelompok lain. Mereka memilih nilai-nilai Islam tumbuh dalam Negara Kesatuan Republik Indonesia (NKRI), karena menyadari bahwa Indonesia terdiri dari berbagai macam suku, ras dan agama. Untuk kepentingan mengakomodir semuanya, mereka mereka menggunakan prinsip-prinsip Universalitas Islam untuk 
membangun persatuan negara Republik Indonesia sebagaimana Rasulullah SAW membuat perjanjian yang dikenal dengan Madinah Charter (Piagam Madinah). Kondisi masyarakat Indonesia yang majemuk juga ditemukan pada masa Nabi Muhammad ketika menyusun Piagam Madinah tersebut.

\section{Latar Belakang Piagam Madinah}

Nabi Muhammad hijrah ke Madinah pada tahun 622 M. dan disambut dengan baik oleh penduduk kota tersebut. Madinah era baru dalam usaha mengefektifkan dakwahnya, karena Nabi Muhammad SAW memperoleh dukungan kuat dari warganya. Dukungan ini tidak diperoleh secara tiba-tiba, tapi diawali dengan kesepakatan-kesepakatan mereka dengan beliau ketika masih berada di Mekkah, kemudian tumbuh dengan perlahan-lahan. Namun, dukungan itu belum membuat posisi beliau benar-benar mantap, karena penduduk Madinah terbagi ke dalam kelompok-kelompok sosial yang saling berbeda dalam cara pikir dan kepentingan (Pulungan, 1996: 87).

Madinah didiami oleh berbagai golongan suku bangsa Arab dan bangsa Yahudi, yang menganut agama dan keyakinan yang berbeda-beda masyarakat Madinah yang majemuk yaitu terdiri dari kaum muslimin (kaum Anshar dan Muhajirin), bangsa Yahudi (bani Quraizah, bani Nadhir, dan bani Qoinuqo', dan bangsa Arab yang belum memeluk Islam (Abidin, 1975: 93). Kemajemukan ini bertambah kompleks setelah sebagian penduduknya memeluk agama Islam dan setelah Nabi Muhammad beserta pengikutnya dari Mekkah hijrah ke kota Madinah. Heterogenitas penduduk Madinah tidak hanya didasarkan atas perbedaan agama dan keyakinan tetapi juga dalam hal etnis, bangsa, asal daerah, kelas sosial serta adat kebiasaan. Hal ini yang menyebabkan tiap golongan memiliki corak pikir dan bertindak sesuai dengan filosofi hidup dan kepentingannya. Faktor-faktor ini pulalah yang tampaknya sering mengakibatkan mudahnya timbul konflik antara mereka.

Tipe masyarakat demikian memerlukan penataan dan pengendalian sosialpolitik secara bijak dengan membuat undang-undang dan peraturan yang dapat menciptakan rasa aman, damai atas dasar keserasian dan keadilan, serta dapat diterima seluruh golongan. Idiologi yang dibangun oleh nabi adalah idiologi pemersatu dengan bahasa yang bisa diterima oleh berbagai pihak, yaitu, kemanusiaan.

Nabi Muhammad SAW mempunyai kedudukan, bukan saja sebagai kepala agama, tetapi sebagai juga sebagai kepala Negara. Dengan kata lain, dalam diri nabi terkumpul dua kekuasaan, kekuasaan spiritual dan kekuasan 
duniawi. Kedudukannya sebagai rasul secara otomatis merupakan kepala Negara (Yatim, 1998:25). Beliau membuat penataan dan pengendalian sosial yang mengatur hubungan antar golongan dalam kehidupan sosial, ekonomi, politik, dan agama, dengan tahapan-tahapan berikut:

Langkah pertama, membangun masjid yang selain sebagai tempat ibadah juga digunakan sebagai tempat musyawarah. Langkah kedua, menciptakan persaudaraan yang nyata antara orang Islam Madinah dan Mekkah. Untuk memperkokoh persatuan dan kesatuan, kelompok kaum mukminin dipersaudarakan atas dasar akidah yang intinya adalah kasih sayang dan kerjasama. Dengan cara itu, mereka semakin kokoh karena tidak ada lagi perbedaan antara pendatang (Muhajirin) dan pribumi (Anshar). Bahkan, ikatan mereka melebihi ikatan kekeluargaan, sehingga, al Quran menggambarkan bahwa: "Mereka (kaum Anshar) mengutamakan (kaum Muhajirin) atas diri mereka, sekalipun mereka membutuhkan apa yang mereka berikan itu". (QS Al Hasyr: 9). "Sesungguhnya orang-orang Mu'min adalah bersaudara karena itu damaikanlah antara kedua saudaramu dan bertakwalah kepada Allah supaya kamu mendapat rahmat." (QS Al Hujurat: 10). Langkah ketiga, membuat perjanjian tertulis atau piagam yang ditujukan untuk seluruh penduduk Madinah (Pulungan, 1996: 63-64).

\section{Piagam Madinah sebagai Dasar Persatuan Masyarakat Plural Madinah}

Nabi Muhammad SAW, dalam membuat piagam tersebut, tidak hanya memperhatikan kepentingan atau kemaslahatan masyarakat muslim saja, melainkan juga memperhatikan kemaslahatan masyarakat non muslim. Hal ini dilakukan Nabi dalam rangka memperkokoh masyarakat dan Negara yang baru saya dibentuk. Nabi adalah sosok yang bisa diterima oleh berbagai golongan, dan sekaligus mampu mempersatukan persepsi dari berbagai keragaman yang ada, tanpa meninggalkan atau menanggalkan karakter masing-masing suku, agama, ras, etnis tersebut.

Piagam Madinah menjadi landasan bagi tujuan utama untuk mempersatukan penduduk Madinah secara integral yang terdiri dari unsur-unsur heterogen. Beliau tidak hendak menciptakan persatuan orang-orang muslim saja secara eksklusif, terpisah dari komunitas-komunitas lain dari wilayah itu. Oleh karenanya ketetapan-ketetapan piagam menjamin hak semua kelompok sosial dengan memperoleh persamaan dalam masalah-masalah umum, sosial, politik sehingga beliau diterima oleh semua pihak, termasuk kaum Yahudi (Pulungan, 1996: 107). Hal ini merupakan bukti nyata kemampuan Nabi Muhammad 
melakukan negosiasi dan konsolidasi dengan berbagai golongan masyarakat Madinah, sejak awal pembentukan Negara tersebut.

Dengan penetapan (arrangement) Piagam Madinah itu, Nabi Muhammad berhasil membangun masyarakat yang bersatu dari unsur-unsur heterogen, Multikultur; yaitu Muslim, Yahudi, Nasrani, penganut paganism, dan Kabilah/ suku yang ada disamping menciptakan persaudaraan nyata di kalangan Muhajirin dan Ansar. Di dalam masyarakat yang bersatu itu, Muhammad diakui memiliki kekuasaan tertinggi untuk menyelesaikan berbagai masalah (konflik horizontal) yang timbul di kalangan mereka (Pulungan, 1996: 108).

\section{Piagam Madinah sebagai Konstitusi Negara}

Masyarakat di bawah pimpinan Nabi Muhammad di Madinah dapat disebut sebagai Negara, beliau sebagai kepala negara, dengan undang-undangnya berupa Piagam Madinah. Mengenai Piagam Madinah ini, para ahli memberi nama yang berbeda-beda dan berarti berimplikasi pada fungsi dan kedudukan yang berbeda pula.

Pertama, shahiffah (Piagam Madinah) disebut Perjanjian (treaty), karena Nabi membuat perjanjian persahabatan antara Muhajirin dan Ansar sebagai komunitas Islam di satu pihak dan antara kaum muslimin dan kaum Yahudi serta sekutu-sekutu mereka di pihak lain, agar mereka terhindar dari pertentangan suku serta bersama-sama mempertahankan keamanan Kota Madinah dari serangan musuh, sehingga dapat hidup berdampingan secara damai sebagai inti dari persahabatan.

Kedua, disebut piagam (charter), karena isinya mengakui hak-hak kebebasan beragama dan berkeyakinan, kebebasan berpendapat dan kehendak umum warga Madinah supaya keadilan terwujud dalam kehidupan mereka, mengatur kewajiban-kewajiban kemasyarakatan semua golongan, menetapkan pembentukan persatuan dan kesatuan semua warga dan prinsip-prinsipnya untuk menghapuskan tradisi dan peraturan kesukuan yang tidak baik.

Ketiga, disebut konstitusi/undang-undang (constitution), karena di dalamnya terdapat prinsip-prinsip untuk mengatuir kepentingan umum dan dasar-dasar sosial politik yang bekerja untuk membentuk suatu masyarakat dan pemerintah sebagai wadah persatuan penduduk Madinah yang majemuk tersebut.

Disebut apapun Piagam Madinah itu, ia dapat mencakup semua pengertian ketiga istilah tersebut. Sebab ia adalah dokumen perjanjian persahabatan antar kaum Muhajirin-Ansor-Yahudi dan sekutunya bersama Nabi yang menjamin 
hak-hak mereka, menetapkan kewajiban-kewajiban mereka dan memuat prinsiprinsip pemerintah yang bersifat fundamental yang sifatnya mengikat untuk mengatur pemerintahan di bawah pimpinan Nabi Muhammad SAW.

Naskah Piagam atau Perjanjian tertulis yang disebut sebagai Shahifat terdiri dari 48 pasal yang isinya menekankan pada persatuan yang erat di kalangan kaum muslimin dan kaum Yahudi, menjamin kebebasan beragama bagi semua golongan, menekankan kerja sama dan persamaan hak dan kewajiban semua golongan dalam kehidupan sosial politik, untuk mewujudkan pertahanan dan perdamaian, dan menetapkan wewenang bagi nabi untuk menengahi dan memutuskan segala perbedaan pendapat dan perselisihan yang timbul di antara mereka (Pulungan, 1996: 64).

Piagam Madinah yang berisi sepuluh (10) bab tersebut secara lebih rinci mencakup: Muqadimah; Bab I: Pembentukan Ummat: berisi satu pasal, Bab II: Hak Asasi Manusia: berisi 9 pasal, Bab III: Persatuan Seagama: berisi 5 pasal, Bab IV: Persatuan Segenap Warganegara: berisi 9 pasal, Bab V: Golongan Minoritas: berisi 12 pasal, Bab VI: Tugas Warganegara: berisi 3 pasal, Bab VII: Melindungi Negara: berisi 3 pasal, Bab VIII: Pemimpin Negara: berisi 3 pasal, Bab IX: Politik Perdamaian: berisi 2 pasal, dan Bab X: Penutup: berisi satu pasal.

Pokok atau prinsip-prinsip yang terdapat dalam konstitusi Madinah, para ahli yang berbeda-beda dalam membuat rumusannya. Muhammad Kholid merumuskan 8 prinsip (Pulungan, 1996: 118). 1) Kaum Muhajirin dan Anshar serta siapa saja yang ikut berjuang bersama mereka adalah umat yang satu, 2) orang-orang mukmin harus bersatu mengahadapi orang bersalah dan mendurhaka walaupun itu anaknya sendiri. 3) jaminan Tuhan hanya satu dan sama untuk semua melindungi orang-orang kecil. 4) orang-orang mukmin harus saling membela diantara mereka dan membela golongan lain, dan siapa saja kaum Yahudi yang mengikuti mereka berhak memperoleh pembelaan dan bantuan seperti yang diperoleh orang muslim. 5) perdamaian orang muslim itu adalah satu.6) bila terjadi persengketaan di antara rakyat yang beriman, maka penyelesaiannya dikembalikan kepada hukum Tuhan dan kepada Muhammad sebagai kepala Negara. 7) kaum Yahudi adalah umat yang satu bersama kaum muslimin. Mereka bebas memeluk agama mereka. 8) sesungguhnya tetangga adalah seperti diri kita sendiri, tidak boleh dilanggar haknya dan tidak boleh berbuat kesalahan kepadanyan.

Zainal Abidin Ahmad dalam bukunya "Membentuk Negara Islam" merumuskan Piagam Madinah ke dalam 10 pokok dasar, yaitu 1) Menyatakan 
berdirinya Negara baru (Negara Islam) dengan warga (umat yang satu) yang terdiri dari orang-orang Muhajirin, Ansar, penduduk asli lainnya dan Yahudi. 2) mengakui hak-hak asasi mereka dan menjamin keamanan dan perlindungan dari segala pembunuhan dan kejahatan. 3) menghidupkan semangat kesetiaan dan persatuan di kalangan kaum agama (Islam). 4) mengatur masyarakat yang bersikap toleran di setiap warga Negara yang beragam agama dan suku bangsanya. 5) mempertahankan hak-hak kaum minoritas, yaitu kaum Yahudi yang menjadi warga Negara. 6) menetapkan tugas setiap warga Negara terhadap negaranya, baik mengenai ketaatan dan kesetiaan maupunnya maupun mengenai soal keuangan. 7) mengumumkan daerah Negara dengan kota Madinah menjadi ibu kotanya. 8) menetapkan Nabi Muhammad sebagai kepala Negara yang memegang pimpinan dan menyelesaikan segala soal. 9) menyatakan politik perdamaian terhadap segala orang dan segala Negara. 10) menetapkan sanksi-sanksi bagi orang-orang yang tidak setia kepada Piagam Madinah ini serta akhirnya memohonkan taufik dan perlindungan dari tuhan terhadap Negara baru itu (Abidin, 1956: 78-81).

Kalau dicermati, maka Piagam/Konstitusi Madinah tersebut merupakan contoh teladan dalam sejarah kemanusiaan untuk membangun masyarakat yang beragam. Selebihnya hal ini tidak hanya dalam gagasan sebagaimana tertuang dalam Piagam Madinah, tetapi juga dalam praktek Nabi dalam memimpin masyarakat Madinah. Bahkan ide-ide dalam ketetapan-ketetapannya mempunyai relevansi kuat dengan perkembangan dan keinginan masyarakat internasional dewasa ini, dan sejalan dengan pandangan hidup modern berbagai negara di dunia yang berpaham humanis, pluralisme dan multikulturalisme. Hal ini dapat dibandingkan dengan isi berbagai piagam, konstitusi, dan deklarasi hak-hak asasi manusia yang lahir puluhan abad kemudian, termasuk pula dengan Piagam Jakarta yang kemudian melahirkan Pancasila.

\section{Piagam Jakarta (22 Juni 1945)}

Pada tanggal 22 Juni 1945 sembilan tokoh nasional yang juga tokoh-tokoh Dokuritso Junbi Chooisakai mengadakan pertemuan untuk membahas pidato serta usul-usul mengenai asas dasar yang telah dikemukakan dalam sidang-sidang Badan Penyelidik Usaha-usaha Persiapan Kemerdekaan Indonesia (BPUKI), untuk itu disusunlah sebuah piagam yang kemudian terkenal dengan nama "Piagam Jakarta", yang di dalamnya terdapat rumusan dan sistematika yang kelak menjadi Pancasila sebagai berikut: 1) Ketuhanan, dengan kewajiban menjalankan syariat Islam bagi pemuluk-pemeluknya, 2) Kemanusiaan yang 
adil dan beradab, 3) Persatuan Indonesia, 4) Kerakyatan yang dipimpin oleh hikmah kebijaksanaan dalam permusyawaratan perwakilan, dan 5) Keadilan bagi seluruh rakyat Indonesia.

Adapun sembilan tokoh nasional itu adalah: Ir. Soekarno, Drs. Mohammad Hatta, A.A. Maramis, Abikusno Tjokrosujoso, Abdulkahar Muzakir, H. Agus Salim, Achmad Subardjo, K.H. Wachid Hasjim, dan Mr. Muhammad Yamin. (Darmodiharjo, 1981: 30).

Dalam sidang-sidang perumusan dasar negara, terlihat ada dua paham. Pertama, yang menganjurkan agar Indonesia didirikan sebagai negara Islam, kedua, anjuran negara nasionalis-sekuler, seperti diusulkan Hatta, yaitu negara persatuan nasional yang memisahkan unsur negara dan agama, bukan negara Islam. Ternyata di dalam Naskah Persiapan UUD 1945 jilid II yang disusun oleh Yamin tidak memuat satupun pidato para anggota nasionalis Islam. Yang dimuat dalam naskah tersebut hanyalah tiga, yaitu (1) pidato Soekarno, (2) pidato Yamin, dan (3) pidato Soepomo.

Piagam Jakarta adalah hasil kompromi tentang dasar negara Indonesia yang dirumuskan oleh Panitia Sembilan dan disetujui pada tanggal 22 Juni 1945 antara pihak Islam dan kaum kebangsaan (nasionalis). Panitia Sembilan merupakan panitia kecil yang dibentuk oleh BPUPKI. Pada saat penyusunan UUD pada Sidang Kedua BPUPKI, Piagam Jakarta dijadikan Muqaddimah (preambule). Selanjutnya pada pengesahan UUD 45 pada tanggal 18 Agustus 1945 oleh Panitia Persiapan Kemerdekaan Indonesia (PPKI). UUD 45 yang telah disahkan oleh PPKI terdiri dari dua bagian, yaitu bagian "pembukaan" dan bagian "batang tubuh UUD" yang berisi 37 Pasal, 1 Aturan Peralihan terdiri atas 4 pasal, 1 Aturan Tambahan terdiri 2 Ayat. ( Darmodiharjo, 1981:30). Istilah Muqaddimah diubah menjadi Pembukaan UUD setelah butir pertama diganti menjadi Ketuhanan Yang Maha Esa. Perubahan butir pertama dilakukan oleh Drs. M. Hatta atas usul A.A. Maramis setelah berkonsultasi dengan Teuku Muhammad Hassan, Kasman Singodimedjo dan Ki Bagus Hadikusumo.

Fakta sejarah tersebut menunjukan bahwa, pemikir bangsa telah arif dan bijaksana untuk menghilangkan keegoisan dalam memaksakan keyakinan salah satu agama terhadap agama lain dalam satu negara. Akhirnya Pancasila tercipta, dan dapat diterima oleh berbagai kelompok yang ada. Kearifan inilah yang harus dijaga bersama, agar kerukunan negara ini tidak terusik oleh keegoisan kelompok tertentu yang ingin memaksakan kehendaknya, di tengah pluralitas bangsa ini. 


\section{Pancasila sebagai Konstitusi Negara Indonesia}

Pancasila adalah dasar negara Republik Indonesia, Pancasila juga merupakan pandangan hidup atau filosofi hidup bangsa Indonesia. Pancasila berarti lima dasar, atau lima asas. Nama ini terdiri dari dua kata dari Sansekerta: pañca berarti lima dan la berarti prinsip atau asas. Istilah Pancasila telah dikenal sejak zaman Majapahit pada abad XIV, yang terdapat pada buku Nagarakertagama karangan Prapanca dan buku Sutasoma karangan Tantular. Dalam buku Sutasoma inilah istilah Pancasila di samping mempunyai arti " berbatu sendi yang lima" (dari bahasa Sansekerta), juga mempunyai arti "pelaksanaan kesusilaan yang lima" (Pancasila Krama) (Darmodiharjo, 1981: 15)

Lima sendi utama penyusun Pancasila adalah Ketuhanan Yang Maha Esa, kemanusiaan yang adil dan beradab, persatuan Indonesia, kerakyatan yang dipimpin oleh hikmat kebijaksanaan dalam permusyawaratan/perwakilan, dan keadilan sosial bagi seluruh rakyat Indonesia, dan tercantum pada paragraf ke-4 Preambule (Pembukaan) Undang-undang Dasar 1945.

Pancasila selanjutnya dituangkan dalam wujud berbagai aturan-aturan dasar pokok, seperti yang terdapat dalam Batang Tubuh UUD 1945 dalam bentuk pasalpasalnya, yang kemudian dijabarkan lagi ke dalam berbagai Ketetapan MPR serta peraturan perundang-undangan lainnya secara tertulis, sedangkan yang tidak tertulis terpelihara dalam konvensi atau kebiasaan kewargaan dan ketatanegaraan. Dalam kaitan ini Pancasila mempunyai sifat mengikat dan keharusan atau bersifat imperatif, artinya sebagai norma hukum yang tidak boleh dilanggar atau dikesampingkan. Apabila nilai-nilai normatif dalam Pancasila tersebut dilanggar, maka yang bersangkutan dikenai sanksi hukum. Misalnya jika ada warga negara Indonesia yang melakukan tindak pidana korupsi, pembunuhan, perampokan, pemerkosaan, penghinaan dan lainnya, maka orang tersebut akan dikenai hukuman secara fisik/dipenjara sesuai dengan berat-ringannya tindak pidana tersebut. Hukum ini berlaku kepada siapa saja, tidak pandang orang, apakah dia sebagai rakyat biasa atau seorang pejabat negara (Subandi, 2003: 9).

Pancasila disebut juga sebagai sumber dari segala sumber hukum karena Pancasila melahirkan dan menjadi landasan sumber-sumber hukum sebagaimana disebutkan di atas. Sebagai dasar negara, Pancasila dituntut untuk bersifat statis dan dinamis. Sifat statis karena Pancasila harus relatif tetap tidak berubah. Sifat dinamis karena Pancasila telah mendorong pengembangan ide dan konsep-konsep pembangunan. Dengan demikian maka seluruh dinamika kehidupan kenegaraan, kebangsaan dan kemasyarakatan di Indonesia lahir 
atas dorongan Pancasila dan didasarkan pula kepadanya.

\section{Piagam Madinah dan Pancasila sebagai Kalimah Muhammad SAW}

Pancasila dan Piagam Madinah tidak hanya mengisyaratkan kesejajaran pada penerimaan kelompok-kelompok beragam akan nilai-nilai kemanusiaan universal, tetapi juga mengimplikasikan adanya hak dan kewajiban yang sama pada kelompok-kelompok bersangkutan untuk menjaga keharmonisan dalam kehidupan berbangsa.

Piagam Madinah Rasulullah berimplikasi pada adanya kewajiban membela keutuhan dan pelaksanaan dari setiap penyelewengan dan penghianatan. Kaum muslimin di Madinah telah melaksankan kewajiban mereka dengan sebaikbaiknya ketika mereka harus menghadapi penghianatan demi penghianatan kelompok-kelompok Yahudi dari Bani Qoinuqa dan Bani Quraidhah. Kaum Muslimin tetap berpegang pada nilai-nilai serta semangat Piagam itu, dan dengan setia melaksanakannya, bahkan mereka mengembangkan sayap politik sesudah wafatnya Rasulullah SAW.

Sama halnya dengan apa yang telah dilakukan kaum Muslimin Madinah terhadap Piagam mereka itu, umat Islam Indonesia juga berkewajiban membela Pancasila untuk menjaga keutuhan dan keharmonisan berbangsa dan bernegara, maupun dalam perincian pelaksanaannya, serta berkewajiban mempertahankan nilai kesepakatan itu dari setiap bentuk penghianatan terhadap keutuhan NKRI.

Pancasila dan Piagam Madinah memiliki kesamaan sebagai Kalimah SAW atau perjanjian luhur. Pancasila merupakan perjanjian luhur seluruh bangsa untuk membangun, mencintai dan mempertahankan Indonesia. Demikian pula dengan Piagam Madinah yang disusun untuk maksud yang kurang lebih sama. Berdasarkan pemikiran di atas, sudah selayaknya jika kaum Muslim, sebagai komunitas terbesar dituntut memiliki komitmen kuat dalam pelaksanan Pancasila secara benar. Demikian pula halnya dengan dihilangkannya tujuh kata dalam Piagam Jakarta, tidaklah berarti sebagai kekalahan perjuangan politik umat Islam, bukan pula kita tidak setuju kalau syariah Islam tegak di bumi Indonesia. Hal ini dapat ditunjukkan beberapa alasan (Tobroni,dkk., 1994: 75);

Pertama, yang paling intens melakukan perubahan naskah Piagam Jakarta justru tokoh-tokoh Islam sendiri terutama; Moh. Hatta, Ki Bagus Hadikusuma dan KH. Wahid Hasyim. Ki Bagus Hadikusuma lah yang mengusulkan sila pertama dengan rumusn "Ketuhanan Yang Maha Esa". Menurut beliau 
rumusan demikian dikatakan lebih menekankan akidah tauhid, sementara rumusan dalam Piagam Jakarta lebih menekankan syari'at (Anwar, 1993: 34) dengan demikian Piagam Jakarta disusun dengan dorongan agama dan kemanusiaan.

Kedua, perubahan Piagam Jakarta menunjukkan sikap demokratis bapak bangsa yang dengan besar hati memahami kecenderungan dan keragaman yang ada. Hal itu juga menunjukkan usaha menghindari dominasi dan monolitik sektarian mayoritas.

Dengan demikian, tepatlah pernyataan KH. Ahmad Sidiq pada tahun 1972 bahwa, Pancasila merupakan bentuk final jauh sebelum pemerintah berusaha menetapkan Pancasila sebagai asas tunggal bagi Orpol dan Ormas. Walaupun pada masa itu kesimpulan demikian belum dikemukakan di depan publik, namun beliau telah terus menerus mensosialisasikannya di depan kalangan warga NU.

Salah satu konsekuen penting dari Pancasila, sebagaimana Piagam Madinah, ialah adanya jaminan kebebasan beragama. Prinsip beragama ini menyangkut halhal yang begitu rumit, karena berkaitan dengan segi-segi emosional dan perasaan mendalam kehidupan kita. Oleh karena masalah ini sangat sensitif, maka bahasa agama yang dipakai adalah bahasa universal, "Ketuhanan Yang Maha Esa", tidak dengan redaksi ” Tegaknya Syariat Islam”, NII (Negara Islam Indonesia), atau tegaknya Khilafah Islamiyah. Jika dulu kalimat ini yang dipakai, maka akan terjadi konflik horisontal, misalnya Kristen dan agama lain tidak akan tinggal diam. Dalam hal ini, bukan hal yang tidak mungkin jika mereka juga ingin mendirikan Negara Kristen Indonesia, seperti yang dicita-citakan orang Islam.

Pelaksanaan prinsip-prinsip kebebasan beragama akan berjalan dengan baik jika masing-masing mampu mencegah emosionalitas atas pelaksanaan prinsipprinsip kebebasan beragama atas pertimbangan akal yang sehat. Kemampuan itu menyangkut tingkat kedewasaan dan kesadaran tertentu serta kemantapan terhadap diri sendiri, baik dalam tingkat individu maupun tingkat kolektif. Dalam al Quran prinsip kebebasan beragama itu dengan tegas dihubungkan dengan sikap tanpa emosi, perbandingan akal sehat dan kemantapan kepada diri sendiri tersebut, karena percaya akan adanya kejelasan mana yang benar dan mana yang palsu (QS al Baqarah: 156).

Kedewasaan dan kemantapan umat Islam di Timur Tengah juga merupakan bukti nyata. Dengan sikap sepeti itu memungkinkan mereka memegang kepemimpinan dalam kemajemukan masyarakat Timur Tengah 
sampai sekarang. Hanya Imperialisme barat yang mengganggu keserasian sosial yang plural di negeri-negeri Muslim itu dengan diciptakan tragedi-tragedi yang sangat ironis seperti Palestina. Sementara itu, dapat dikatakan bahwa adanya kesadaran umat Islam terdahulu dan kemampuannya untuk hidup dalam semangat pluralisme sosial pada tahap perkembangan sejarah dunia yang begitu dini merupakan entitas penting yang mendukung keteguhan dan eksistensi agama Islam hingga kini.

Dalam Piagam Madinah, Nabi Muhammad SAW meletakkan asas-asas kemasyarakatan, antara lain adalah: al ikha', al MuSAWah, al tasamuh, al tasyawur, al ta'awun dan al adalah (Maryam, dkk., 2002: 39). Al ikha' (Persaudaraan), merupakan salah satu asas penting masyarakat Islam yang diletakkan Rasulullah. Sebelumnya bangsa Arab menonjolkan identitas dan loyalitas kesukuannya, setelah masuknya Islam identitas diganti dengan identitas Islam. Atas dasar ini Rasulullah mempersaudarakan Muhajirin dan Anshar. Rasul mempersaudarakan Abu Bakar dengan Haritsah bin Zait, Ja'far bin Abi Tholib dengan Muadz bin Jabal dan lain-lain. Dengan demikian keluarga-keluarga Muhajirin dan Ansor dipertalikan dengan persaudaraan berdasarkan agama, menggantikan persaudaran berdasarkan nasab dan kesukuan.

Al Musawah (persamaan), yaitu bahwa manusia adalah sama keturunan nabi Adam yang diciptakan dari tanah. Berdasarkan asas ini setiap warga masyarakat memiliki hak kemerdekaan dan kebebasan (hurriyah). Rasul sangat memuji para sahabt yang memerdekakan budak-budak dari tangan orangorang Quraisy.

Al Tasamuh (toleransi), Piagam Madinah memuat asas toleransi, dimana umat Islam siap dan mampu berdampingan dengan kaum Yahudi. Mereka mendapat perlindungan dan kebebasan dalam melaksanakan agamanya masingmasing. Asas ini dipertegas dalam al Quran surat Al Kafirun: 6. Al Tasyawur (Musyawarah) sebagaimana diisyaratkan dalam surat Ali Imran ayat 159. Kendati Rasul memiliki status yang tinggi dan terhormat dalam masyarakat, beliau seringkali meminta pendapat para sahabat dalam menghadapi permasalahanpermasalahan yang berkaitan dengan urusan dunia dan sosial budaya. Pendapat para sahabat kerap kali diikuti manakala dianggap benar.

Al Ta'awun (tolong menolong). Tolong menolong sesama muslim telah dibuktikan dengan mempersaudarakan kaum Muhajirin dengan kaum Anshor, sedangkan dengan pihak lain sesama penduduk Madinah, isi dalam Piagam Madinah merupakan bukti kuat berkaitan denagn asas ini.

Al Adalah (keadilan) berkaitan erat dengan hak dan kewajiban setiap 
individu dalam kehidupan bermasyarakatsesuai dengan posisi masing-masing. Prinsip ini berpedoman pada surat al Maidah ayat 8 dan surat an Nisa' ayat 58.

Asas-asas dalam Piagam Madinah tersebut, tampaknya juga terkandung dalam butir-butir dari masing-masing ke lima sila Pancasila. Hal ini menunjukkan bahwa dalam penyusunannya Pancasila sangatlah dipengaruhi oleh prinsipprinsip agama Islam. Para tokoh yang terlibat dalam pembentukan Pancasila merupakan tokoh-tokoh muslim yang memiliki kapasitas keagamaan yang tinggi memahami prinsip-prinsip kenegaraan dan kemasyarakatan sesuai dengan prinsip-prinsip yang terdapat dalam Piagam Madinah. Setiap prinsip dalam lima sila Pancasila (prinsip ketuhanan, persatuan, kemanusiaan, musyawarah dan keadilan) merupakan prinsi-prinsip yang terkandung dalam Piagam Madinah yang telah dilaksanakan Rasulullah SAW dan para khalifah rasyidah dalam menjalankan pemerintahan.

\section{Simpulan}

Piagam Madinah memuat ide yang mempunyai relevansi kuat dengan perkembangan dan keinginan masyarakat dunia dewasa ini, bahkan telah menjadi pandangan hidup modern di berbagai negara. Ide dalam Konstitusi Madinah juga diserap oleh para tokoh pendiri bangsa Indonesia, yang dapat dilihat dalam Piagam Jakarta yang kemudian melahirkan Pancasila.

Muatan Piagam Madinah dan Pancasila memiliki kesamaan sebagai kalimah SAW atau perjanjian luhur yang membangun, mencintai dan mempertahankan Indonesia. Demikian pula dengan Piagam Madinah, merupakan perjanjian luhur untuk mempertahankan negara Madinah. Keduanya sama-sama memuat asas-asas dan prinsip-prinsip: persaudaraan, persamaan, toleransi, musyawarah, tolong menolong, dan keadilan.

\section{Daftar Pustaka}

Abidin, Zainal. 1956. Membentuk Negara Islam. Jakarta: Bulan Bintang

Abidin, Zainal. 1975. Piagam Nabi Muhammad SAW. Konstitusi Negara Yang Pertama di Dunia Jakarta: Bulan Bintang

Anwar, M. Syafi', Politik Agama dan Artikulasi Politik Islam dalam Orde Baru, Media Indonesia, Jum'at 19 Pebruari, 1993.

Darmodiharjo, Dardji, dkk. 1981. Santiaji Pancasila. Surabaya, Usaha 


\section{Nasional}

Karim, M. Abdul. 2004. Menggali Muatan Pancasila dalam Perspektif Islam. Jogjakarta: Surya Raya

Karvallo, Bosco dan Dasrizal, (ed). 1983. Aspirasi Umat Islam Indonesia. Jakarta; Leppenas

Khan, Muhammad Zafrulh. 1980. Muhammad Seal of the Propheat, London

Maryam, Siti, dkk. 2002. Sejarah Peradaban Islam dari Masa Klasik hingga Modern. Yogyakarta: Jurusan SPI Fak. Adab IAIN Sunan Kalijaga bekerjasama dengan LESFI.

Pulungan, Suyuti. 1996. Prinsip-prinsip Pemerintah dalam Piagam Madinah Ditinjau dari Pandangan Al Quran Jakarta: Rajawali Pers.

Subandi AlMarsudi. 2003. Pancasila dan UUD'45 dalam Paradigma Reformasi. Jakarta: PT. Raja Grafindo Persada.

Tobroni dan Syamsul Arifin. 1994. Islam Pluralisme Budaya dan Politik. Jogjakarta: Spires.

Yatim, Badri. 1998. Sejarah Peradaban Islam. Jakarta: Rajawali pers. 